\title{
Penggunaan Metode Bernyanyi dalam Menghafal Mufrodat (Kosakata) Bahasa Arab di MI
}

\author{
Ali Imron ${ }^{*}$, Dewi Farda Fajriyyah ${ }^{2}$ \\ ${ }^{1}$ Universitas Wahid Hasyim, Semarang \\ ${ }^{2}$ SDN Srondol Wetan 06
}

\begin{abstract}
This article aims to determine the effect of the singing method on the ability to memorize mufrodats (vocabulary) in MI Baitul Huda. This research is a quantitative research with data collection techniques in the form of written tests, questionnaires, interviews, observation and documentation. The data collection analysis used statistical analysis. Based on the results of the questionnaire answered by 22 respondents, it shows a mean with a value of 72 indicating an increase in the ability to memorize mufrodat al-fawaakih material for the experimental class students using the singing method with an average value of 90.90 while the control class with the conventional method obtained an average of 66 90. The effect of the use of the singing method on the ability to memorize mufrodates from the results of the hypothesis test can be seen that the $r$-count is 0.582 , while the $r$-table is at a significant level of $1 \%=0.537$ and $5 \%=0.423$. The significance level of $1 \% \mathrm{r}$-count (0.582)> from the $r$-table (0.537), while the significant level of $5 \% r$-count (0.582) > from the r-table (0.423). So it can be ascertained that there is a significant effect of using the singing method on the ability to memorize mufrodats.
\end{abstract}

Keywords: Singing Method, Memorizing Mufrodat, Arabic

\begin{abstract}
Abstrak
Artikel ini memiliki tujuan mengetahui pengaruh metode bernyanyi terhadap kemampuan menghafal mufrodat (kosakata) di MI Baitul Huda. Penelitian ini merupakan penelitian kuantitatif dengan teknik pengumpulan data berupa tes tertulis, angket, wawancara, observasi dan dokumentasi. Adapun analisis pengumpulan data menggunakan analisis statistik. Berdasarkan hasil angket yang dijawab oleh 22 responden menunjukkan mean dengan nilai 72 menunjukkan adanya peningkatan kemampuan menghafal mufrodat materi al-fawaakih peserta didik kelas eksperimen menggunakan metode bernyanyi dengan nilai rata-rata 90,90 sedangkan kelas kontrol dengan metode konvensional memperoleh rata-rata 66,90. Pengaruh penggunaan metode bernyanyi terhadap kemampuan menghafal mufrodat dari hasil uji hipotesis dapat diketahui r-hitung diperoleh 0,582, sedangkan r-tabel pada taraf signifikan $1 \%=0,537$ dan $5 \%=0,423$. Taraf signifikan $1 \% \mathrm{r}$-hitung $(0,582)>$ dari $\mathrm{r}$ tabel $(0,537)$, sedangkan taraf signifikan $5 \%$ r-hitung $(0,582)>$ dari r-tabel $(0,423)$. Maka dapat dipastikan adanya pengaruh yang signifikan penggunaan metode bernyanyi terhadap kemampuan menghafal mufrodat.
\end{abstract}

Kata Kunci: Metode Bernyanyi, Menghafal Mufrodat, Bahasa Arab. 


\section{A. Pendahuluan}

Bahasa Arab sebagai salah satu bahasa asing di Indonesia memiliki peranan penting, terlebih lagi bagi umat Islam sebagai salah satu alat untuk bias memahami kandungan atau makna dari sumber ajaran Islam yakni Alquran dan Hadits. Bahasa Arab (Anshor, 2009) sebagai bahasa agama mempunyai pengertian bahwa pemahaman terhadap ajaran-ajaran agama yang benar merupakan suatu keharusan bagi para pemeluknya.

Firman Allah Swt. dalam surat Yusuf ayat 2 menegaskan bahwasanya Alquran sebagai sumber utama hukum Islam berbahasa Arab. Untuk itu memepelajari bahasanya menjadi penting untuk mendapatkan pemahaman saying mendekati benar atau sesuai dengan yang diinginkan. Selain itu, kemampuan berbahasa adalah sesuatu yang harus dimiliki oleh setiap orang. Bahasa yang ada ragamnya sangat banyak dan berbeda-beda baik dari segi asalusul, rumpun, atau unsur-unsur yang berpengaruh di dalamnya. Bahasa Arab merupakan bahasa mayor di dunia, bahasa yang digunakan secara resmi kurang lebih 20 negara karena merupakan bahasa kitab suci dan tuntunan agama umat Islam sedunia (Arsyad, 2010).

Mufrodat (kosakata) merupakan salah satu bahasan penting yang harus dimiliki oleh seseorang dalam mempelajari bahasa asing, termasuk juga Bahasa Arab (Muna, 2011). Perbendaharaan kosakata Bahasa Arab yang mencukupi dapat menunjang seseorang berkomunikasi dan menulis dengan baik menggunakan bahasa tersebut. Berbicara dan menulis merupakan kemahiran berbahasa dengan faktor pendukung utama pengalaman dan penguasaan kosakata yang kaya dan produktif. Penambahan kosakata dianggap penting bagi proses pembelajaran suatu bahasa ataupun pengembangan kemampuan seseorang dalam suatu bahasa yang sudah dikuasai, untuk itu diperlukan metode yang tepat dalam rangka pembelajaran kosakata Bahasa Arab agar kebutuhan perbendaharaan kosakata dalam pembelajaran tercapai.

Bahasa Arab memiliki keistimewaan dan ciri khas tersendiri yang membedakan dengan bahasa yang lainnya. Di antara keistimewaannya adalah di samping sebagai bahasa sastra yang paling kaya dari segi lafaz dan makna di 
seluruh dunia, ia juga merupakan bahasa yang paling mampu mengekspresiskan keindahan bahasa. Sebagaimana bahasa-bahasa lain memiliki asal-usul sejarah dan perkembangan. Bahasa Arab mula-mula berasal, tumbuh, dan berkembang di kawasan timur tengah, lebih dari itu Bahasa Arab (Abidin \& Satrianingsih, 2018) menyebar di dunia internasional hingga diterima dan dinyatakan sebagai salah satu bahasa resmi internasional.

Suatu fenomena demotivasi dalam pembelajaran Bahasa Arab pada jenjang pendidikan dimana istilah demotivasi ini mengacu pada suatu stimulus yang menahan dilakukannya perbuatan tertentu. Dalam konteks pembelajaran Bahasa Arab, demotivasi mengacu pada suatu stimulus baik itu terencana maupun tidak terencana yang menyebabkan pelaksana pendidikan (siswa, guru, kepala Sekolah) maupun stakeholders lainnya yang terkait menahan atau menghambat, mengurangi, bahkan menghilangkan spirit belajar Bahasa Arab bagi siswa maupun guru.

Tahun sebelum sembilan puluhan, keberadaan mata pelajaran Bahasa Arab di madrasah merupakan mata pelajaran prestisius. Mata pelajaran Bahasa Arab selalu mendapat apresiasi yang tinggi dari pihak madrasah dan sekaligus sebagai matapelajaran kebanggaan. Akan tetapi, setelah tahun sembilan puluhan, secara perlahan namun pasti, keberadaan mata pelajaran Bahasa Arab di madrasah, kurang mendapatkan apresiasi yang proporsional. Inilah yang disebut sebagai gejala demotivasi.

Fenomena lain yang mengisyaratkan demotivasi tercermin pada hasil survey terbatas pada MTs dan MA Negeri dan swasta di Kota Malang. Hasil survey terbatas yang dilaksanakan pada pertengahan tahun 2010 menunjukkan bahwa bahasa asing yang menjadi pilihan utama adalah bahasa Inggris (79\%), bahasa Arab (20\%) dan bahasa Jepang (1\%). Alasan pemilihan bahasa Inggris sebagai pilihan utama lebih bersifat pragmaits-instrumental, yakni untuk bekerja, studi lanjut, dan karena bahasa Inggris merupakan salah satu mata pelajaran yang di-UN-kan. Sementara itu, alasan pemilihan Bahasa Arab lebih dekat sebagai motivasi integratif, yakni untuk melanjutkan studi Bahasa Arab ke perguruan tinggi dan Bahasa Arab sebagai bahasa agama (Fajriyyah, 2019). 
Ada dua faktor utama yang menyebabkan fenomena demotivisasi dalam pembelajaran bahasa Arab ini terjadi, yaitu faktor internal dan eksternal. Faktor internal terkait dengan implementasi sistem pembelajara bahasa Arab. Faktor eksternal lebih bersifat makro yang lebih terkait dengan variable-variabel di luar sistem pembelajaran yang secara langsung maupun tidak langsung menyebabkan demotivasi pembelajaran bahasa Arab terjadi. Salah satu faktor internal yaitu kurangnya metode yang bervariatif, sehingga perlu adanya sesuatu yang baru yang bisa menumbuhkan semangat dan minat pada diri setiap siswa supaya ada kemauan pada siswa untuk belajar bahasa Arab.

Salah satu cara menyenangkan yang bisa digunakan adalah dengan bernyanyi. Bernyanyi adalah salah satu aktifitas yang sangat digemari sebagian besar masyarakat, terutama untuk kalangan anak-anak (Yusriana, 2012). Peserta didik akan lebih mudah menangkap dan mengingat suatu pelajaran dengan proses yang menyenangkan dan menghibur, dari pada mendengarkan ceramah yang serius. Metode bernyanyi dijadikan suatu metode yang dapat menarik minat belajar peserta didik dalam belajar mata pelajaran Bahasa Arab. Madrasah Ibtidaiyah (MI) adalah suatu lembaga pendidikan formal yang lebih menekankan pendidikan agama di dalamnya. Mata pelajaran bahasa Arab telah diberikan mulai dari kelas satu sampai enam.

Metode bernyanyi ini digunakan untuk menarik minat peserta didik dalam belajar Bahasa Arab. Metode bernyanyi dapat membantu anak usia dini belajar bahasa Arab lebih menyenangkan (Ridwan \& Awaluddin, 2019). Tidak hanya untuk anak usia dini tetapi juga untuk anak usia MTs (Nisa et al., 2020) sehingga metode bernyanyi berpengaruh signifikan dalam mengingat huruf dan angka bagi anak-anak (Kamtini \& Sitompul, 2020).

Tujuan penggunaan metode bernyanyi adalah agar peserta didik yang takut, malas dan tidak menyukai Bahasa Arab menjadi tertarik dan senang dalam mengikuti pembelajaran. Metode ini bisa memberi warna baru dalam pembelajaran Bahasa Arab, melalui bernyanyi peserta didik dapat mengekspresikan segala pikiran dan isi hatinya. Lagu (Jannah, 2013) juga dapat menguatkan daya ingat, karena melalui sesuatu yang menarik dan menyenangkan akan lebih mudah teringat dalam pikiran. 
Kemampuan menghafal mufrodat siswa kelas 1 tergolong lemah, karena menurut pengamatan guru peserta didik merasa jika Bahasa Arab adalah salah satu mata pelajaran yang sulit karena mempelajari bahasa asing. Untuk itu, perlu adanya metode pembelajaran untuk membantu peserta didik dapat menguasai Bahasa Arab, salah satunya menggunakan metode bernyanyi, agar pembelajaran menarik bagi peserta didik.

Beberapa penelitian yang memiliki persinggungan dengan tema di atas antara lain yang dilakukan (Faqihuddin, 2014), (Maftuchah, 2016), (Dewi, 2017), dan (Triatnasari, 2017) yang meneliti metode bernyanyi. Berbeda dengan penelitian sebelumnya, nilai kebaruan dari penelitian ini yaitu memfokuskan kemampuan menghafal mufrodat (kosakata Bahasa Arab) dengan bantuan metode bernyanyi pada kelompok ekperimen dan kontrol materi al Fawaakih.

\section{B. Metode Penelitian}

Pendekatan penelitian ini menggunakan desain kuantitatif eksperimen yang digunakan untuk mencari pengaruh perlakuan tertentu terhadap yang lain dalam kondisi yang terkendalikan (Sugiyono, 2016). Jenis metode penelitian eksperimen yang digunakan adalah penelitian eksperimen True Experimental Design Type Pretest-Posttest Control Group Design. Desain penelitian menggunakan True Experimental. Peneliti melakukan kontrol semua variabel luar yang memengaruhi jalannya eksperimen. Bentuk desain dalam penelitian ini adalah Pretest-Posttest Control Group Design.

Populasi dalam penelitian ini ialah peserta didik MI Baitul Huda Klampisan Ngaliyan Semarang tahun pelajaran 2018/2019 berjumlah 160. Sampelnya adalah kelas I berjumlah 43 dilakukan pengambilan sampel acak sederhana dilakukan dengan cara undian dari daftar bilangan secara acak. Pengumpulan data untuk mendapatkan data penggunaan metode bernyanyi dalam pemeblajaran Bahasa Arab ini menggunakan cara tes dan non tes. Non tes meliputi: angket, wawancara, observasi dan dokumentasi.

Analisis data yang dilakukan adalah analisis pendahuluan dilanjutkan analisis uji instrumen soal berupa uji validitas menggunakan rumus korelasi poin 
biserial $R p b i=\frac{M p-M t}{S D t} \sqrt{\frac{p}{q}}$ dan uji reliabilitas untuk menghitung reliabilitas tes pilihan ganda menggunakan rumus $r_{11}=\left[\frac{k}{k-1}\right]\left[1-\frac{\sum \sigma b^{2}}{\sigma t^{2}}\right]$, setelah diperoleh harga $r_{11}$ kemudian dikonsultasikan dengan $r_{\text {tabel }}$. Apabila harga $r_{11}>r_{\text {tabel }}$ maka instrumen tersebut reliabel.

Adapun analisis uji hipotesis untuk membuktikan apakah ada pengaruh positif metode bernyanyi terhadap kemampuan menghafal mufrodat kelas 1 mata pelajaran Bahasa Arab materi al-Fawaakih pada peserta MI Baitul Huda menggunakan korelasi product moment dengan rumus:

$$
\begin{aligned}
& r_{x y}=\frac{N \sum X Y-\left(\sum X\right)\left(\sum Y\right)}{\sqrt{\left(N \sum X^{2}-\left(\sum X\right)^{2}\right)\left(N \sum Y^{2}-\left(\sum Y\right)^{2}\right)}} \\
& \text { Keterangan: } \\
& \mathrm{r}_{\mathrm{xy}}=\text { Angka Indeks Korelasi "r" Product Moment } \\
& \mathrm{N}=\text { Jumlah Responden } \\
& \sum \mathrm{XY} \quad \text { = Jumlah Hasil Perkalian Variabel } \mathrm{X} \text { dan } \mathrm{Y} \\
& \sum \mathrm{X}=\text { Jumlah Variabel } \mathrm{X} \\
& \sum \mathrm{Y}=\text { Jumlah Variabel } \mathrm{Y}
\end{aligned}
$$

Analisis uji hipotesis yang peneliti lakukan menggunakan rumus product moment sehingga dapat diketahui hasil penelitian kemudian diinterprestasikan dengan menggunakan $r_{\text {hitung }}$ dan $r_{\text {tabel }}$, dengan taraf signifikan $1 \%$ dan $5 \%$. Peneliti menggunakan taraf 5\% sehingga hasil yang diperoleh tingkat kesalahannya bisa lebih signifikan dengan kemungkinan.

\section{Hasil dan Pembahasan}

\section{Kemampuan Menghafal Mufrodat (kosakata) dengan Metode Bernyanyi}

\section{pada kelas I materi Al-Fawaakih di MI Baitul Huda Klampisan}

Di Madrasah Ibtidaiyyah, mata pelajaran Bahasa Arab dipersiapkan untuk pencapaian kompetensi dasar berbahasa yang mencakup empat keterampilan berbahasa yang diajarkan yaitu membaca, menulis, menyimak, dan berbicara. Materi dalam pembelajaran merupakan gambaran pengetahuan yang akan diterima peserta didik setelah mengikuti pembelajaran. Materi al-Fawaakih adalah sub materi mata pelajaran Bahasa Arab yang diberikan kepada peserta didik kelas I Madrasah Ibtidaiyyah. 
Materi al fawaakih (nama-nama buah) disampaikan oleh guru dengan bernyanyi, guru menggubah lirik lagu cublak-cublak suweng dengan namanama buah. Pada pelajaran ini, peserta didik dikenalkan mengenai namanama buah dalam Bahasa Arab dengan nyanyian seperti contoh:

\author{
Nama-nama Buah \\ (Lagu: Cublak-cublak Suweng) \\ Jawwaafatun jambu, Burtuqoolun itu jeruk \\ Mauzun itu pisang, Naarojiilun kelapa \\ 'Inabun itu anggur \\ I itu nama buah, I itu nama buah \\ Bittiihun semangka, baabaayaa itu pepaya \\ manja artinya mangga, tamarun itu kurma \\ faraulatun strawberry \\ I itu nama buah, I itu nama buah
}

Belajar Bahasa Arab berbeda dengan belajar bahasa ibu, oleh karena itu prinsip dasar pengajarannya harus berbeda, baik menyangkut metode, materi maupun proses pelaksanaannya. Setiap anak manusia pada dasarnya memiliki kemampuan yang berbeda-beda. Dalam mata pelajaran Bahasa Arab, kebanyakan guru dalam proses menyampaikan materi hanya menggunakan metode ceramah, tanya jawab, penugasan dan latihan. Maka dari itu siswa kurang dapat mencerna penjelasan yang disampaikan oleh guru. Melihat masalah tersebut maka harus dilakukan perbaikan dengan menggunakan metode yang inovatif.

Kemampuan yang diperoleh peserta didik dalam proses pembelajaran dapat digunakan untuk mengetahui bagaimana tingkat perkembangannya, adapaun kata "mampu" memiliki makna yang sama dengan dapat atau bisa. Kemampuan merupakan daya atau keinginan untuk melakukan sesuatu sebagai hasil pembawaan atau latihan (Susanto, 2017).

Kemampuan menghafal mufrodat dengan metode bernyanyi kelas 1 MI Baitul Huda melalui angket yang didistribusikan kepada responden. Data tersebut dimasukkan ke tabel dengan memberi skor pada alternatif jawaban responden. Skor kemampuan menghafal mufrodat ini diperoleh dari nilai pretest dan posttest melalui lembar soal yang diberikan kepada kelas 1A maupun 1B MI Baitul Huda. Kemampuan menghafal mufrodat dapat diketahui nilai kuantitatif dengan diberikannya lembar pretest kepada kelas 
eksperimen maupun kelas kontrol sebelum diberi perlakuan yang berbeda. Hal ini dapat dilihat dalam tabel distribusi frekuensi untuk menghitung nilai dari data yang terkumpul melalui soal pretest kelas ekperimen yang berjumlah 22 siswa.

Hasil pretest menunjukkan bahwa terdapat 3 siswa yang memperoleh skor pada interval 41-48 dengan kategori sangat kurang, terdapat 4 siswa yang memperoleh skor pada interval 49-56 dengan kategori kurang, terdapat 7 siswa yang memperoleh skor pada interval 57-64 dengan kategori cukup, terdapat 5 siswa yang memperoleh skor pada interval 65-72 dengan kategori baik, terdapat 3 siswa yang memperoleh skor pada interval 73-80 dengan kategori sangat baik. Hasil perolehan skor pretest eksperimen kemampuan menghafal mufrodat materi al-fawaakih yaitu dengan nilai tertinggi 80 dan nilai terendah 45, artinya pretest eksperimen sebelum diberi perlakuan menggunakan metode bernyanyi pada kelas 1A MI Baitul Huda adalah cukup.

Hasil perolehan skor pretest kontrol kemampuan menghafal mufrodat materi al-fawaakih yaitu dengan nilai tertinggi 80 dan nilai terendah 40, artinya pretest kontrol sebelum diberi perlakuan pada kelas 1B MI Baitul Huda adalah cukup.

\section{a. Analisis posttest eksperimen kemampuan menghafal mufrodat}

Kemampuan menghafal mufrodat dapat diketahui nilai kuantitatif dengan diberikannya lembar posttest kepada kelas eksperimen maupun kelas kontrol setelah diberi perlakuan yang berbeda. Hasilnya pada kelas eksperimen menunjukkan bahwa terdapat 3 siswa yang memperoleh skor pada interval 71-76 dengan kategori sangat kurang, terdapat 1 siswa yang memperoleh skor pada interval 77-82 dengan kategori kurang, terdapat 2 siswa yang memperoleh skor pada interval 83-88 dengan kategori cukup, terdapat 3 siswa yang memperoleh skor pada interval 89-94 dengan kategori baik, terdapat 13 siswa yang memperoleh skor pada interval 95100 dengan kategori sangat baik.

Hasil di atas menunjukkan mean dengan nilai 90,90 dibulatkan menjadi 91 dari nilai posttest tergolong baik, karena termasuk interval 89- 
94. Hasil perolehan skor posttest eksperimen kemampuan menghafal mufrodat materi al-fawaakih yaitu dengan nilai tertinggi 100 dan nilai terendah 75, artinya posttest eksperimen setelah diberi perlakuan menggunakan metode bernyanyi pada kelas 1A MI Baitul Huda adalah Baik.

Hasil posttest untuk kelas control menunjukkan bahwa terdapat 5 siswa yang memperoleh skor pada interval 41-50 dengan kategori sangat kurang, terdapat 3 siswa yang memperoleh skor pada interval 51-60 dengan kategori kurang, terdapat 5 siswa yang memperoleh skor pada interval 61-70 dengan kategori cukup, terdapat 4 siswa yang memperoleh skor pada interval 71-80 dengan kategori baik, terdapat 4 siswa yang memperoleh skor pada interval 81-90 dengan kategori sangat baik. Hasil analisis menunjukkan mean dengan nilai 66,90 dibulatkan menjadi 67 dari nilai posttest tergolong cukup, karena termasuk interval 61-70. Hasil perolehan skor posttest kontrol kemampuan menghafal mufrodat materi alfawaakih yaitu dengan nilai tertinggi 90 dan nilai terendah 45, artinya posttest kontrol setelah diberi perlakuan menggunakan metode konvensional pada kelas 1B MI Baitul Huda adalah cukup.

\section{b. Analisis Uji Hipotesis dan Analisis Lanjut}

Analisis uji hipotesis adalah tahapan pembuktian dari kebenaran hipotesis yang telah diajukan. Analisis ini akan menggunakan rumus korelasi product moment yaitu sebagai berikut:

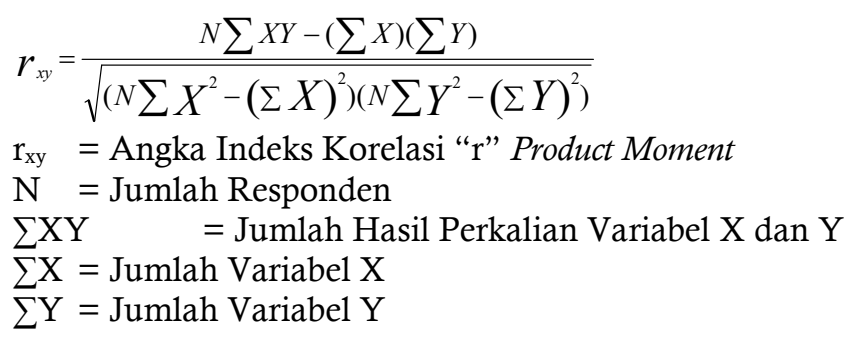

Diketahui hasil r-hitung yaitu 0,582 yang berkisar antara $0,40-0,70$, berdasarkan pedoman yang ada pada tabel 4.18 dapat kita nyatakan bahwa antara variabel $\mathrm{X}$ dan variabel $\mathrm{Y}$ itu mempunyai korelasi yang "sedang atau cukup". Secara sederhana dapat diinterpretasikan bahwa 
korelasi antara metode bernyanyi (variabel X) dan kemampuan menghafal mufrodat (variabel Y) itu merupakan korelasi yang "sedang atau cukup".

Adapun langkah selanjutnya pada tahap lanjut ini adalah mengujinya atau menginterpretasikan dengan menggunakan nilai "rxy (rproduct moment)". Membandingkan besarnya "r-hitung" dengan "r-tabel". Diketahui r-hitung diperoleh 0,582, sedangkan r-tabel pada taraf signifikan $1 \%=0,537$ dan $5 \%=0,423$. Taraf signifikan $1 \%$ r-hitung $(0,582)>$ dari r-tabel $(0,537)$, sedangkan taraf signifikan 5\% r-hitung $(0,582)>$ dari r-tabel $(0,423)$. Hal ini berarti hipotesis yang diajukan yaitu "ada pengaruh penggunaan metode bernyanyi terhadap kemampuan menghafal mufrodat (kosakata) mata pelajaran Bahasa Arab kelas I MI Baitul Huda Klampisan Ngaliyan Semarang" dapat diterima dan terbukti kebenarannya.

Simpulannya adalah bahwa variabel $\mathrm{X}$ dan varibel $\mathrm{Y}$ menunjukkan signifikan atau adanya pengaruh yang positif. Hasil interpretasi taraf signifikan $1 \%$ dan $5 \%$ hasil yang diperoleh adalah r-hitung lebih besar dari r-tabel, jadi hipotesis yang telah diajukan dalam bab 1 hasilnya adalah signifikan atau hipotesis diterima dan terbukti kebenarannya. Semakin baik dalam menerapkan metode bernyanyi maka semakin baik respon siswa dan kemampuan menghafal mufrodat (kosakata) siswa mata pelajaran Bahasa Arab kelas I MI Baitul Huda Klampisan Ngaliyan Semarang.

\section{Analisis Pengaruh Metode Bernyanyi terhadap Kemampuan Menghafal Mufrodat (Kosakata) Bahasa Arab Kelas I MI Baitul Huda Klampisan}

Kemampuan menghafal diartikan sebagai kemampuan untuk memindahkan bahan bacaan atau objek kedalam ingatan, menyimpan di dalam memori dan pengungkapan kembali pokok bahasan yang ada dalam memori (Sa'dullah, 2008). Menghafal juga dapat dikatakan suatu kegiatan menyerap informasi ke dalam otak yang dapat digunakan dalam jangka panjang (Indianto, 2017). Kosakata dalam bahasa Arab atau yang disebut dengan mufrodat, yang merupakan kumpulan kosakata yang digunakan oleh 
seseorang baik secara lisan maupun tulisan yang sudah memiliki pengertian dan uraian terjemahannya tanpa dirangkaikan dengan kata-kata lain serta tersusun secara abjadiyah.

Kemampuan menghafal mufrodat (kosakata) adalah kesanggupan seseorang dalam menguasai kosakata dengan diucapkan diluar kepala tanpa melihat buku atau catatan dari pembelajaran tersebut. Untuk mencapai kemampuan menghafal mufrodat yang baik perlu ditunjang dengan desain metode yang tepat dan sesuai dengan perkembangan anak. Metode yang digunakan dalam penelitian ini ialah metode bernyanyi untuk menghafalkan kosakata Bahasa Arab. Diharapkan setelah proses pembelajaran Bahasa Arab menggunakan metode bernyanyi siswa dapat merasa senang, tidak merasa bosan, lebih semangat dan dapat menghafal mufrodat (kosakata) yang telah diajarkan serta hasil belajar juga memuaskan.

Metode pengumpulan data pada penelitian ini yaitu tes, angket, wawancara, observasi, dan dokumentasi. Pengolahan data telah dilakukan pada tahap awal analisis peneliti memperoleh data pengaruh metode bernyanyi melalui hasil angket yang telah dibagikan terhadap 22 responden sebanyak 20 butir pernyataan. Hasil dari analisis tahap pendahuluan hasil angket pengaruh metode bernyanyi terhadap kemampuan menghafal mufrodat (kosakata) Bahasa Arab kelas I MI Baitul Huda Klampisan Ngaliyan Semarang tergolong "Baik" dan termasuk dalam interval (70-74) yaitu berjumlah 13 responden dan mempunyai skor yang paling banyak diantara yang lainnya. Artinya hasil angket pengaruh metode bernyanyi dalam pembelajaran Bahasa Arab di kelas I MI Baitul Huda Klampisan Ngaliyan Semarang tergolong "Baik".

Pembelajaran sebelum dimulai, dengan menggunakan metode bernyanyi untuk kelas eksperimen dan metode konvensional (ceramah) pada kelas kontrol, terlebih dahulu diadakan pretest pada siswa kelas eksperimen (1A) dan kelas kontrol (1B) mengenai materi al-fawaakih untuk mengetahui kondisi awal kedua kelas tersebut sebelum memperoleh pembelajaran.

Soal Pretest berasal dari soal yang telah diujicobakan sebelumnya terhadap kelas 2 yaitu kelas yang sebelumnya telah mendapat materi al- 
fawaakih Bahasa Arab. Uji coba dilakukan untuk mengetahui apakah butir soal baik atau belum. Adapun alat yang digunakan dalam pengujian analisis uji coba meliputi validitas tes dan reliabilitas tes.

Tahap uji instrumen soal, yang pertama uji validitas dengan menggunakan rumus poin biserial yaitu untuk mengetahui valid tidaknya item-item soal. Butir soal dalam uji validitas ini sebanyak 25 butir, peneliti membagikannya kepada responden dan kemudian peneliti analisis dan dari 25 butir soal tersebut, diperoleh jumlah soal yang valid sebanyak 20 butir soal dan yang tidak valid 5 soal. Butir soal yang valid akan digunakan sebagai soal pretest posttest, sedangkan soal yang tidak valid tidak akan digunakan sebagai soal pretest posttest. Uji reliabilitas adalah sama dengan konsistensi atau keajegan, menunjukkan data yang reliabel dengan skor 0,810 sedangkan $r-$ tabel dengan taraf signifikan 5\% dari $\mathrm{n}=27-2$ diperoleh 0,381 , karena $\mathrm{r}$-hitung > r-tabel maka koefisien butir soal tersebut reliabel.

Hasil awal ketuntasan belajar kelas eksperimen dan kelas kontrol berdasarkan hasil nilai pretest yang dilakukan sebelum kegiatan pembelajaran dengan jumlah 20 butir soal pilihan ganda, kelas eksperimen (IA) dapat diketahui dari total 22 siswa yang mengikuti tes diperoleh rata-rata nilai 60 , sedangkan untuk kelas kontrol (1B) diketahui dari total 21 siswa yang mengikuti tes diperoleh rata-rata nilai 53,81.

Analisis tahap akhir didasarkan pada nilai posttest yang diberikan kepada siswa baik kelas eksperimen maupun kelas kontrol. Proses pembelajaran kedua kelas mendapat perlakuan yang berbeda yaitu kelas eksperimen (1A) yang berjumlah 22 siswa menggunakan metode bernyanyi sedangkan kelas kontrol (1B) yang berjumlah 21 siswa menggunakna metode konvensional. Proses setelah pembelajaran berakhir, kelas eksperimen dan kelas kontrol diberi tes akhir (posttest).

Kelas eksperimen (1A) diberi perlakuan yaitu pembelajaran Bahasa Arab materu al-fawaakih dengan menggunakan metode bernyanyi. Guru memberikan pengantar singkat tentang pelaksanaan metode bernyanyi. Guru meyampaikan materi al-fawaakih kepada siswa bahwa materi tersebut artinya buah-buahan. Materi yang telah diterima siswa kemudian dimodifikasi 
dengan lagu yang disukai siswa, dalam penelitian menggunakan lagu cublakcublak suweng. Guru mencontohkan bagaimana cara bernyanyinya kemudian siswa mengikutinya. Siswa mengulanginya di rumah dengan bimbingan orang tua.

Kelas kontrol (1B) pada pembelajaran Bahasa Arab materi al-fawaakih tanpa menggunakan metode bernyanyi. Pembelajaran pada kelas kontrol hanya berlangsung satu arah yaitu siswa diberikan pengajaran menggunakan metode konvensional (ceramah). Seorang guru menyampaikan informasi di depan kelas kemudian siswa mendengarkan dan mengerjakan soal yang diberikan oleh guru. Hal ini mengakibatkan kejenuhan dan pembelajaran menjadi monoton, sehingga siswa tidak termotivasi untuk aktif mencari informasi sendiri karena kegiatan siswa saat pembelajaran hanya duduk dan mendengarkan apa saja yang disampaikan oleh gurunya.

Perlakuan yang berbeda dilakukan antara kelas eksperimen dan kelas kontrol kemudian diadakan tes akhir yaitu posttest dengan 20 butir soal pilihan ganda. Kelas eksperimen (1A) dapat diketahui dari total 22 siswa yang mengikuti tes diperoleh ratarata 90,90, sedangan untuk kelas kontrol (1B) diketahui dari total 21 siswa yang mengikuti tes diperoleh rata-rata 66,90.

Hasil penelitian dapat dikemukakan bahwa metode bernyanyi berpengaruh terhadap kemampuan menghafal mufrodat dalam materi alfawaakih mata pelajaran Bahasa Arab. Hal ini ditunjukkan adanya peningkatan kemampuan menghafal mufrodat siswa pada materi al-fawaakih setelah mendapatkan perlakuan berbeda dari nilai awal kelas eksperimen 60 dan kelas kontrol 53,81 meningkat menjadi kelas eksperimen 90,90 dan kelas kontrol 66,90,

Tahap hasil uji analisis hipotesis kelas eksperimen dapat diketahui hasil dari r-hitung diatas yaitu 0,582 yang berkisar antara 0,40-0,70, berdasarkan pedoman yang ada pada tabel di atas dapat kita nyatakan bahwa antara variabel $\mathrm{X}$ dan variabel $\mathrm{Y}$ itu mempunyai korelasi yang "Sedang atau Cukup". Kita interpretasikan secara sederhana bahwa korelasi antara metode bernyanyi (variabel X) dan kemampuan menghafal mufrodat (variabel Y) itu merupakan korelasi yang "sedang atau cukup". 
Tahap analisis uji lanjut diketahui r-hitung diperoleh 0,582, sedangkan r-tabel pada taraf signifikan $1 \%=0,537$ dan $5 \%=0,423$. Taraf signifikan $1 \%$ r-hitung $(0,582)>$ dari r-tabel $(0,537)$, sedangkan taraf signifikan 5\% r-hitung $(0,582)>$ dari r-tabel $(0,423)$. Hal ini berarti hipotesis yang diajukan yaitu "ada pengaruh penggunaan metode bernyanyi secara signifikan terhadap kemampuan menghafal mufrodat mata pelajaran Bahasa Arab di kelas I MI Baitul Huda Klampisan Ngaliyan Semarang" dapat diterima dan terbukti kebenarannya.

Simpulannya adalah bahwa variabel $\mathrm{X}$ dan varibel $\mathrm{Y}$ menunjukkan signifikan atau adanya pengaruh yang positif. Hasil interpretasi taraf signifikan $1 \%$ dan 5\% hasil yang diperoleh adalah $r$-hitung lebih besar dari $\mathrm{r}$ tabel, jadi hipotesis yang telah diajukan dalam bab 1 hasilnya adalah signifikan atau hipotesis diterima dan terbukti kebenarannya. Hasilnya juga dikemukakan bahwa kemampuan menghafal mufrodat dengan menggunakan metode bernyanyi lebih baik dari kemampuan menghafal mufrodat siswa yang menggunakan metode konvensional pada materi al-fawaakih. Oleh karena itu metode bernyanyi berpengaruh pada proses pembelajaran Bahasa Arab materi al-fawaakih yang bertujuan mengukur kemampuan menghafal mufrodat siswa kelas 1 MI Baitul Huda Klampisan Ngaliyan Semarang.

Berdasarkan kajian teori dengan hasil penelitian yang telah dilakukan didapatkan bahwa penggunaan metode bernyanyi dalam kemampuan menghafal mufrodat (kosakata) dapat meningkatkan daya tangkap dan daya ingat dalam proses pembelajaran. Temuan peneliti memberikan petunjuk bahwa pendekatan pembelajaran menggunakan metode bernyanyi serta sekolah memberikan keleluasaan untuk menggunakan metode tersebut dalam proses pembelajaran.

Strategi pembelajaran dan mendeskripsikan bagaimana cara menerapkan praktik metode bernyanyi yang berdasar pada proses pembelajaran dapat mempengaruhi hasil pembelajaran dan bagaimana mereka dapat diajari serta dapat meningkatkan pembelajaran secara dramatis.

Interaksi mengajar yang aktif baik guru maupun siswa dapat dijadikan pertimbangan dasar dalam menampilkan keterampilan secara tepat. Peran 
guru, sekolah dan orang tua harus ikut mempedulikan, mempunyai suatu komunikasi dengan siswa. Hal ini akan memberikan atmosfer yang baik untuk siswa dalam belajar.

Simpulan kajian teori dengan hasil penelitian yaitu aktivitas siswa dalam pembelajaran bisa lebih optimal apabila materi yang diberikan merangsang dan menarik minat belajar siswa, salah satunya dapat menerapkan metode bernyanyi. Implementasi metode bernyanyi terhadap kemampuan menghafal mufrodat (kosakata), siswa dapat terbantu dalam aspek kognitif dan psikomotoriknya. Penelitian ini memiliki tujuan dapat meningkatkan mutu pendidikan dikemudian hari.

\section{Kesimpulan}

Berdasarkan penelitian didapatkan hasil kemampuan menghafal mufrodat siswa kelas eksperimen dengan menggunakan metode bernyanyi memperoleh nilai rata-rata 90,90 sedangkan kelas kontrol dengan metode konvensional memperoleh rata-rata 66,90. Besarnya pengaruh penggunaan metode bernyanyi terhadap kemampuan menghafal mufrodat yaitu dari hasil uji hipotesis dapat diketahui $r$-hitung diperoleh 0,582 , sedangkan $r$-tabel pada taraf signifikan $1 \%=$ 0,537 dan $5 \%=0,423$. Taraf signifikan $1 \%$ r-hitung $(0,582)>$ dari r-tabel $(0,537)$, sedangkan taraf signifikan $5 \% \mathrm{r}$-hitung $(0,582)>$ dari r-tabel $(0,423)$. Maka hipotesis alternatif diterima bahwa "ada pengaruh penggunaan metode bernyanyi terhadap kemampuan menghafal mufrodat pada pembelajaran Bahasa Arab materi al-fawaakih siswa kelas I MI Baitul Huda Klampisan Ngaliyan Semarang".

\section{Daftar Pustaka}

Abidin, Z., \& Satrianingsih, A. (2018). Perkembangan dan Masa Depan Bahasa Arab. Diwan: Jurnal Bahasa Dan Sastra Arab, 3(2). https://doi.org/10.24252/diwan.v3i2.4459

Anshor, A. M. (2009). Pengajaran Bahasa Arab Media dan Metode-metodenya. Teras.

Arsyad, A. (2010). Bahasa Arab dan Metode Pengajarannya. Pustaka Pelajar.

Dewi, M. (2017). Penerapan Metode Bernyanyi untuk Meningkatkan Daya Ingat Anak dalam Pengenalan Huruf Hijaiyyah di TPA Darul Falah Gampong Pineung. UIN Ar- 
Raniry Darussalam Aceh.

Fajriyyah, D. F. (2019). Pengaruh Penggunaan Metode Bernyanyi terhadap Kemampuan Menghafal Mufrodat (Kosakata) pada Pembelajaran Bahasa Arab Siswa Kelas I Materi Al-Fawaakih di MI Baitul Huda Klampisan Ngaliyan Semarang Tahun Pelajaran 2018/2019. Universitas Wahid Hasyim.

Faqihuddin, A. R. (2014). Upaya Meningkatkan Penguasaan Mufrodat melalui Penerapan Metode Permainan Edukatif di Kelas VIII MTs Hidayatulloh. UIN Sunan Kalijaga Yogyakarta.

Indianto, A. (2017). Kiat-Kiat Mempertajam Daya Ingat Hafalan Pelajaran. Diva Press.

Jannah, L. A. (2013). Kesalahan-kesalahan Guru PAUD yang Sering Dianggap Sepele. Diva Press.

Kamtini, K., \& Sitompul, F. A. (2020). Pengaruh Metode Bernyanyi terhadap Kemampuan Mengingat Huruf dan Angka pada Anak Usia Dini. Jurnal Obsesi: Jurnal Pendidikan Anak Usia Dini, https://doi.org/10.31004/obsesi.v4i1.295

Maftuchah, M. (2016). Peningkatan Hasil Belajar Penguasaan Kosakata Bahasa Arab Melalui Metode Lagu Materi Al-Adawatul Madrosiyyah Tugu Semarang Tahun Ajaran 2015/2016. Universitas Wahid Hasyim Semarang.

Muna, W. (2011). Wa Muna. Teras.

Nisa, I. K., Rahmi, N., \& Fajri, W. (2020). Penerapan Metode Bernyanyi dalam Meningkatkan Penguasaan Kosa Kata Bahasa Arab di MTs Ma'arif NU 07 Purbolinggo. Arabia: Jurnal Pendidikan Bahasa Arab, 12(2). https://doi.org/10.21043/arabia.v12i2.7878

Ridwan, R., \& Awaluddin, A. F. (2019). Penerapan Metode Bernyanyi dalam Meningkatkan Penguasaan Mufradat dalam Pembelajaran Bahasa Arab di Raodhatul Athfal. Didaktika: Jumal Kependidikan, 13(1). https://doi.org/10.30863/didaktika.v13i1.252

Sa'dullah. (2008). Cara Cepat Menghafal Al-Quran. Gema Insani.

Sugiyono. (2016). Metode Penelitian Kuantitatif, Kualitatif, dan R\&D. Alfabeta.

Susanto, A. (2017). Pendidikan Anak Usia Dini (Konsep dan Teori). Bumi Aksara.

Triatnasari, V. (2017). Penggunaan Metode Bernyanyi dalam Meningkatkan Hasil Belajar Siswa pada Pembelajaran Matematika Kelas IIIB MIN II Bandar Lampung Tahun Pelajaran 2016/2017. UIN Raden Intan Lampung.

Yusriana, A. (2012). Kiat-kiat Menjadi Guru PAUD yang Disukai Anak-anak. Diva Press. 